\title{
Utsikt til innsikt: En komparativ tilnærming til reform av reglene om anke til lagmannsretten over dommer i sivile saker
}

Av Magne Strandberg og Anna Nylund

Reglene om anke til lagmannsretten ble revidert da tvisteloven ble vedtatt i 2005, men mye tyder på at revisjonen ikke har virket helt etter hensikten. Reglene har flere ganger senere blitt foreslått endret. I denne artikkelen blir det argumentert for at det bør gjøres mer grunnleggende endringer av ankereglene enn det som hittil har blitt vurdert. Forfatterne hevder at de norske ankereglene i for stor grad åpner for en full omprøving, i stedet for den mer begrensede overprøvingen som var intensjonen med tvisteloven. Ved å sammenligne med rettstilstanden i andre land, særlig Tyskland, Spania, Sverige og Finland, hevder forfatterne at det er mulig å finne inspirasjon til hvordan et system basert på begrenset overprøving kan oppnås, og hvilke hovedgrep som må gjøres i norsk rett for å få innført et slikt system.

NØKKELORD: anke i sivile saker, anke til lagmannsretten, ankesiling, omprøving, overprøving, preklusjon,

Magne Strandberg er professor i rettsvitenskap ved Det juridiske fakultet, Universitetet i Bergen. Han underviser der i sivilprosess og erstatningsrett.

Anna Nylund er professor i rettsvitenskap ved Det juridiske fakultet, UiT - Norges arktiske universitet. Hun underviser i sivilprosess, alternativ konfliktløsning og komparativ rett.

\section{Dagens ankeregler og behovet for reform}

Reglene om anke til lagmannsretten ble inngående diskutert da tvisteloven ble forberedt. ${ }^{1}$

Tvistemålsutvalgets rettspolitiske vurderinger av ankereglene fulgte de samme linjene som resten av reformen. Utvalget trakk først frem at ankereglene er nødvendige for å få riktige avgjørelser:

«Overprøving medfører kvalitetskontroll med avgjørelsene og skaper derved trygghet for partene for at deres tvist får en riktig avgjørelse og en forsvarlig behandling. I et videre perspektiv fremmer dette kvaliteten på domstolene og domstolsarbeidet. Det er av vesentlig betydning for tilliten til domstolene» (NOU 2001: 32 s. 345).

${ }^{1}$ NOU 2001: 32 Rett på sak s. 345-362, Ot.prp. nr. 51 (2004-2005) Om lov om mekling og rettergang i sivile tvister (tvisteloven) s. 289-300, Innst. O. nr. 110 (2004-2005) Innstilling fra justiskomiteen om lov om mekling og rettergang i sivile tvister (tvisteloven) s. 63-66. 
Straks deretter trakk utvalget frem at anke har en kostnadsside, både for domstolene og partene, og at det skal være proporsjonalitet mellom kostnadene i en sak og det som står på spill i saken. ${ }^{2}$ I samsvar med proporsjonalitetshensynet ble reglene om anke til lagmannsretten basert på en sumgrense som skulle beregnes ut fra hva som er normale kostnader ved en ankebehandling. ${ }^{3}$ For alle saker om formuesverdier der ankegjenstandens verdi er under 125000 kroner, skulle en anke fremmes til behandling bare dersom lagmannsretten samtykker, jf. tvl. § 29-13 (1). ${ }^{4}$ For alle saker om formuesverdier over denne verdien og alle saker om ideelle verdier mente flertallet at anken skulle fremmes med mindre lagmannsretten «finner det klart at anken ikke vil føre fram» (§ 29-13 (2)). Flertallet begrunnet sitt standpunkt med proporsjonalitetshensyn og med at en lignende regel gjelder i straffesaker. Mindretallet ønsket ikke at det skulle være anledning til å nekte en anke fremmet. ${ }^{5}$ Flertallets syn ble lagt til grunn i det senere lovarbeidet.

Lagmannsretten skulle ikke lenger gi en full, fornyet behandling av saken. ${ }^{6}$ Ifølge Tvistemålsutvalget la partene i anker over sakens realitet altfor ofte opp til en fullstendig ny behandling, noe som etter den nye tvisteloven skulle erstattes av et system der lagmannsretten konsentrerer behandlingen om det anken gjelder, og som er omtvistet mellom partene. ${ }^{7}$ Tvisteloven skulle legge opp til overprøving, ikke omprøving. Justisdepartementet sluttet seg til dette. ${ }^{8}$ I sin drøftelse av muntlighetsprinsippet og andre trekk ved ankeforhandlingens stil og form var departementet

«fullt ut enig med utvalget $\mathrm{i}$ at en ankeforhandling for lagmannsretten normalt bør ha et vesentlig annet preg enn en hovedforhandling for tingretten. Det har særlig sammenheng med at tingrettens dom vil utgjøre en del av avgjørelsesgrunnlaget, og at ankeforhandlingen skal konsentreres om de spørsmål som partene er uenige om. En ankeforhandling skal med andre ord være noe vesentlig annet enn en fullstendig fornyet behandling, slik ordningen er for straffesaker for så vidt gjelder de deler av saken hvor det er anket over bevisvurderingen» (Ot.prp. nr. 51 (2004-2005) s. 188).

For å få en slik endring av ankebehandlingen skulle den ankende part i større grad enn før konkretisere ankeerklæringen, og på samme vis skulle motparten i større grad enn før konkretisere sitt anketilsvar. ${ }^{9}$ Dessuten skulle dommerens aktive saksstyring sørge for at partenes anke ble klargjort, ${ }^{10}$ og at det bare skulle tillates forhandling om det anken gjaldt.

Mye tyder på at tvistelovens regler om anke til lagmannsretten ikke har fungert helt etter hensikten. Justisdepartementets evaluering av tvisteloven fra 2013 viste at ankeforhandlingene ikke tok så mye kortere tid enn før, man fant en $\varnothing$ kning i antall rettsmøtetimer per sak for lagmannsretten, og bare en liten reduksjon i antall behandlede tvistesaker per dommerårsverk. ${ }^{11}$ Man fant heller ingen reduksjon i

${ }^{2}$ Se generelt om disse hensynene: NOU 2001: 32 s. 131-133.

${ }^{3}$ NOU 2001: 32 s. 776.

${ }^{4}$ Tvistemålsutvalget foreslo at grensen skulle være $2 \mathrm{G}$, slik at den skulle oppjusteres automatisk, NOU 2001: 32 s. 776-777.

${ }^{5}$ NOU 2001: 32 s. $778-780$.

${ }^{6}$ NOU 2001: 32 s. 357 og 783. Om den eldre rettstilstanden under tvistemålsloven: Jens Edvin A. Skoghøy, Tvistemål, 2. utgave, Universitetsforlaget 2001, s. 868-874 og $900 \mathrm{ff.}$

${ }^{7}$ NOU 2001: 32 s. 357.

${ }^{8}$ Ot.prp. nr. 51 (2004-2005) s. 289.

${ }^{9}$ Tvl. §§ 29-9 og 29-11.

${ }^{10}$ Tvl. §§ 11-5 og 29-14 (1).

${ }^{11}$ Justis- og beredskapsdepartementet, Evaluering av tvisteloven, juli 2013, s. 13, 31 og 34. 
tilkjente sakskostnader i saker som hadde vært behandlet i lagmannsretten. ${ }^{12}$ Departementet oppga at de hadde fått tilbakemeldinger om at ankeforhandlingene i praksis fortsatt blir full overprøving, ${ }^{13}$ og la for egen regning til at «de nye reglene om hoved- og ankeforhandling representerer en kulturendring som krever ytterligere tid». ${ }^{14}$

Departementet fulgte opp evalueringen da det i 2018 sendte flere forslag til endringer av tvisteloven ut på høring. ${ }^{15}$ I korte trekk dreier forslagene til endring av ankereglene seg om å gi tydeligere regler om aktiv saksstyring og å øke ankesummen fra 125000 kroner til 250000 kroner. Økningen av ankesummen har allerede blitt foreslått for Stortinget i en egen proposisjon. ${ }^{16}$ En slik økning av ankesummen kan løse noen problemer ettersom den gir lagmannsretten anledning til å gi en temmelig enkel behandling av saker hvor ankesummen er under den nye grensen. Den vil likevel ikke påvirke behandlingen av de mange sakene med en ankesum over 250000 kroner. Det trengs derfor en mer omfattende reform for å løse problemet med at ankeprosessen fortsatt langt på vei er en full omprøving. Justisdepartementet nevnte også i sitt høringsnotat at man vurderer å foreslå mer vidtrekkende regler om ankesiling, men $\emptyset$ nsket et bedre grunnlag før dette eventuelt ble fremmet. ${ }^{17}$ Domstolskommisjonen har som mandat å vurdere begrensninger i adgangen til å få saker behandlet av ankeinstansen og om saksbehandlingen i ankeinstansen kan gjøres mer effektiv. Kommisjonen har trolig bedre muligheter til å skaffe et tilstrekkelig dypt og bredt grunnlag for å revidere ankereglene.$^{18}$

Etter vår oppfatning er det gode grunner til å reformere reglene om anke til lagmannsretten, og å innhente et godt underlagsmateriale $f \varnothing r$ en reform gjennomføres. ${ }^{19}$ Som et element i et slikt $s \varnothing \mathrm{k}$ etter underlagsmateriale er det på sin plass å se til andre land for å få inspirasjon om hvordan ankereglene i sivile saker kan være. ${ }^{20}$ I mange europeiske land ble reglene om anke i sivile saker reformert i samme periode som vi gjennomførte vår tvistelovreform, reformene var preget av de samme formålene, og reglene ble til etter en avveining mellom en grundig prøving som resulterer i et mest mulig riktig resultat, på den ene siden, og effektivitet, proporsjonalitet og domstolstilgang på den andre siden. ${ }^{21}$

${ }^{12}$ Samme sted, s. 16.

${ }^{13}$ Samme sted, s. 36.

${ }^{14}$ Samme sted, s. 13.

${ }^{15}$ Justis- og beredskapsdepartementet, Høringsnotat om Forslag til endringer i tvisteloven tvistelovevalueringen, juli 2018.

${ }^{16}$ Prop. 133 L (2018-2019) Endringer i tvisteloven (verdigrenser) s. 23-28 og 35.

${ }^{17}$ Justis- og beredskapsdepartementet, Høringsnotat om Forslag til endringer i tvisteloven tvistelovevalueringen, juli 2018, s. 60.

${ }^{18} \mathrm{https://www.domstolkommisjonen.no/mandat/} \mathrm{(sist} \mathrm{besøkt} \mathrm{18.09.2019).}$

${ }_{19}$ Slik også Ørnulf Øyen, «Anke til lagmannsretten - ny behandling, begrenset overprøving eller prøving av bestemte temaer?», Lov og Rett, 2018 s. 389-390.

${ }^{20}$ Også tvistemålsutvalget hadde en gjennomgang av det de kaller «fremmed rett», men skuffende nok er det bare svensk rett, dansk rett og amerikansk (!) rett som blir gjennomgått (NOU 2001: $32 \mathrm{~s}$. 347-349). Se andre komparative verk om anke i sivile saker: J. A. Jolowicz, On Civil Procedure, Cambridge University Press 2000, s. 271 ff., og A. Uzelac og C.H. van Rhee (red.), Nobody's Perfect: Comparative Essays in Appeals and other Means of Recourse against Judicial Decisions in Civil Matters, Intersentia 2014.

${ }^{21}$ F.eks. innføringen av den nye spanske sivilprosesskoden fra år 2000, den omfattende tyske reformen fra år 2001, reformen i Sverige fra 2008 og ikke minst innføringen av de nye Civil Procedure Rules i 
Forholdene bør derfor ligge til rette for å se på hvilke regler som ble innført i de ulike land, og hvilke erfaringer de har gjort. ${ }^{22}$ Vi har valgt å se på store europeiske land: Frankrike, Spania og Tyskland. Vi har imidlertid valgt å utelate engelsk rett fra gjennomgangen. Det skyldes at ankereglene der alltid har vært bygget på et system med «leave to appeal», og hvis man i Norge skal hente inspirasjon fra et slikt system, er det nok mer nærliggende å trekke inn svensk og finsk rett. I tillegg er rettsutviklingen i Sverige og Finland interessant med tanke på blant annet lang erfaring med å bruke opptak fra tingretten i ankeprosessen. Rettstilstanden i andre land kan imidlertid, særlig på grunn av språklige barrierer, være vanskelig å få tak på. For å bøte på dette ble det i juni 2019 arrangert en workshop ved Det juridiske fakultet i Bergen hvor utvalgte europeiske eksperter presenterte systemet for anke i deres hjemland. Vår artikkel her er blant annet basert på foredragene de holdt, og det skriftlige materialet de har stilt til vår rådighet. ${ }^{23}$

Vi får ta oss tid til å nevne et par avgrensninger: Vi vil bare skrive om anke til lagmannsretten og tilsvarende anke fra første til andre instans i andre land. Direkte anke til Høyesterett («leapfrog appeal») vil vi ikke skrive om. ${ }^{24}$ Dessuten vil vi bare skrive om anke over dommer avsagt av tingretten og tilsvarende instanser $\mathrm{i}$ andre land, ikke anke over saksstyrende kjennelser eller beslutninger. Ellers $\mathrm{i}$ Europa er adgangen til å anke over saksstyrende kjennelser og beslutninger («interlocutory appeals») atskillig mer begrenset enn hos oss, men diskusjonen om dette er så omfattende at vi har valgt å avgrense mot den. ${ }^{25}$

\section{Svensk og finsk rett}

I svensk og finsk rett er ankeprosessen en utpreget overprøvingsprosess, noe som er en følge av en rekke reformer på 2000-tallet. I Finland er retten til anke beskyttet i grunnloven, ${ }^{26}$ men man tolker grunnloven slik at overprøving oppfyller retten til anke. ${ }^{27}$ Fordi den finske ordningen er basert på den svenske ordningen, behandles disse under ett, og ulikheter trekkes frem bare dersom de er av vesentlig betydning.

England og Wales i 1998. Om disse reformene: Adrian A. S. Zuckerman og Ross Cranston (red.), Reform of Civil Procedure: Essays on 'Access to Justice', Clarendon Press 1995; Adrian A. S. Zuckerman (red.), Civil Justice in Crisis: Comparative Perspectives of Civil Procedure, Oxford University Press 1999; Volker Lipp og Halvard H. Fredriksen (red.), Reforms of Civil Procedure in Germany and Norway, Mohr Siebeck 2011, og John Sorabji, English Civil Justice after the Woolf and Jackson Reforms: A Critical Analysis, Cambridge University Press 2014.

${ }^{22}$ Bruk av komparative analyser for å inspirere nasjonale lovreformer er velkjent i den komparativrettslige litteraturen, se f.eks. Uwe Kischel, Comparative Law, Oxford 2019, s. 54 ff.

${ }^{23}$ Foredragsholderne var professorene Frédérique Ferrand ved Université de Lyon, Christoph Kern ved Universität Heidelberg og Fernando Gascon Inchausti ved Universidad Complutense de Madrid. I tillegg presenterte Magne Strandberg ankereglene i Norge, og Anna Nylund ankereglene i Sverige og Finland.

${ }^{24}$ Nærmere om dette i noen andre land: Neil Andrews, Andrews on Civil Processes (Vol. 1): Court Proceedings, Intersentia 2013, s. 457-458.

${ }^{25}$ Se nærmere om dette i NOU 2001: 32 s. 355-358.

${ }^{26}$ Finlands grundlag 11.6.1999/731 $21 \S 2$ mom.

${ }^{27}$ Dan Frände mfl., Prosessioikeus, 4. utgave, Alma Talent 2012, s. 1147. 
I Finland ankes det over mer enn $25 \%$ av avsagte dommer i sivile saker, mens det ankes over rundt 5 \% i Sverige. ${ }^{28}$ Antallet sivile saker i Finland er meget lavt. Det skyldes at terskelen for å reise søksmål er svært $h \varnothing y$, slik at sakene ofte er av stor betydning for partene, noe som nok $\varnothing$ ker sannsynligheten for at de anker. ${ }^{29}$ I Sverige finnes et stort antall tvistemål med lav verdi, noe som antakelig påvirker andelen ankede avgjørelser. Endringsfrekvensen av antallet innkomne anker var 21,7 \% i Sverige i 2018, 28 \% i Finland. Det finske tallet omfatter imidlertid både straffesaker og sivile saker. ${ }^{30}$

I Sverige og Finland gjelder det en regel om preklusjon mellom underretten og ankeinstansen: Partene får ikke endre sine krav, påstander, det faktiske grunnlaget for dem eller tilby nye bevis med mindre gode grunner foreligger. ${ }^{31}$ Slike grunner er for eksempel at nye faktiske forhold har oppstått, eller at en part blir kjent med et nytt bevis som parten til tross for grundige unders $\varnothing$ kelser ikke oppdaget før hovedforhandlingen i første instans.

Saksbehandlingen i ankedomstolen består av to trinn. På det første trinnet («overprøvingsfasen») avgjør retten om det foreligger en grunn til å fremme saken eller deler av den, altså å innvilge anketillatelse (prövningstillstånd i Sverige, tillstånd om fortsatt handläggning i Finland). På det andre trinnet («omprøvingsfasen») prøves de delene av sakene som er fremmet, og som det er nødvendig å prøve. Ordningen gjelder for alle sivile saker uavhengig av verdi og uavhengig av ankegrunn. I Sverige fremmes noe under $40 \%$ av ankene, i Finland er tilsvarende tall rundt $50 \%{ }^{32}$

Saksbehandlingen på det første trinnet er skriftlig: Retten prøver om det er grunn til å omprøve saken eller deler av den, på grunnlag av ankeerklæringen inkludert skriftlige bevis, underrettens avgjørelse og, ved behov, utskrift av rettsboken med protokoll fra saksforberedende rettsmøter, stevning, tilsvar og skriftveksling. ${ }^{33}$ I ankeerklæringen må parten identifisere hvilke deler av underrettens avgjørelse eller saksbehandling som er gjenstand for anken, og hvordan parten mener disse bør endres, samt grunnlaget

${ }^{28}$ Domstolsverket, Sveriges domstolar, Domstolsstatistik 2018. http://www.domstol.se/upload/Lokala_webbplatser/Domstolsverket/Statistik/Domstolsstatistik\%2 02018.pdf, s. 18-20, og Justitieministeriet, Tuomioistuinten työtilastoja vuodelta 2018. Justitieministeriets publikationer. Verksamhet och förvaltning 2019: 8. http://julkaisut.valtioneuvosto.fi/bitstream/handle/10024/161460/OMTH 20198 Tuomioistuinte n_ty\%c3\%b6tilastoja_vuodelta_2018.pdf?sequence=4\&isAllowed=y, s. 5-6.

${ }^{29}$ For eksempel mener forbrukermyndighetene at tvistesummen bør være rundt 20000 euro, altså nesten 200000 NOK, for at et søksmål skal være forsvarlig. Se også f.eks. Satu Saarensola, «The Risk of Legal Costs and Its Effects on Access to Court» og Laura Ervo og Amie Dahlqvist, «Delays in Civil Proceedings: Comparative Studies Between Finland and Sweden», i Laura Ervo og Anna Nylund (red.), The Future of Civil Litigation: Access to Courts and Court-annexed Mediation in the Nordic Countries, Springer 2014, hhv. s. 231-248 og 249-280.

${ }^{30}$ Domstolsstatistik 2018, s. 18-20 og Tuomioistuinten työtilastoja vuodelta 2018, s. 5-6.

${ }^{31}$ Den svenske Rättegångsbalken Lag 1942:740 (svRB) 50 kap. 4 § 2 st. og den finske Rättegångsbalken (fiRB) Lag 1.1.1734/425 kap. 17 §.

${ }^{32}$ Lina Nestor, Svea hovrätts överprövning i tvistemål - en uppföljning av 2012 års undersökning. http://www.svea.se/Domstolar/sveahovratt/Dokument\%20och\%20PM/Unders\%C3\%B6kning av Svea hovr\%C3\%A4tts \%C3\%B6verpr\%C3\%B6vning i tvistem\%C3\%A5l 2015.pdf, s. 19 og Tuomioistuinten työtilastoja vuodelta 2018, s. 5-6.

${ }^{33}$ Siden man gjør opptak av vitneforklaringer, protokollføres ikke forklaringene. 
for at parten mener at avgjørelsen er feil. ${ }^{34}$ Retten kan innhente anketilsvar $f \varnothing r$ avgjørelsen om anketillatelse fattes. I Sverige kan retten også se på opptak fra underretten, i Finland er det ikke adgang til å høre på opptak.

Anketillatelse kan innvilges av fire grunner. ${ }^{35}$ Den første er at det er grunn til å tvile på at underrettens avgjørelse er riktig. Den andre er at det ikke er mulig å avgjøre om tingrettens avgjørelse er riktig, uten å innvilge anketillatelse. Disse grunnene er i praksis de vanligste. Den tredje grunnen er at saken reiser spørsmål som er viktige å prøve for å oppnå rettsutvikling og rettsenhet. Den fjerde er at det er andre særlige grunner til å prøve saken.

Den andre grunnen, at det ikke er mulig å ta stilling til om avgjørelsen er riktig, er interessant fra et komparativt perspektiv. Spørsmål om rettsanvendelse dekkes normalt av den første ankegrunnen, siden det er mulig å vurdere anken ut fra det tilgjengelige skriftlige materialet, med mindre domsgrunnene er uklare eller mangelfulle. Derimot vil en vurdering av muntlige bevis basert på skriftlig materiale være i strid med umiddelbarhetsprinsippet og muntlighetsprinsippet. Ifølge doktrinene om tilltrobevisning kan retten ikke vurdere om vitnets (eventuelt den sakkyndiges eller partens) observasjon er riktig, eller om vitneforklaringen tilsvarer observasjonen og/eller hva vitnet mener med sin uttalelse, altså i praksis spørsmålet om hvilken vekt vitneutsagnet skal gis, uten å høre vitnet selv eller et opptak av utsagnet. ${ }^{36}$ । Finland må anken derfor i utgangspunktet fremmes dersom den gjelder vurderingen av muntlige bevis. For å unngå at en anke over vurderingen av muntlige bevis innebærer et «frikort» til anketillatelse, kreves at den ankende part sår tvil om bevisvurderingen gjennom å fremsette konkrete holdepunkter til støtte for sine påstander. Dersom partens argumentasjon gir grunn til å tvile på bevisvurderingen, og bevisvurderingen har betydning for avgjørelsens innhold, skal anketillatelse gis. I Sverige har retten anledning til å se på videoopptak fra underretten under behandlingen av anketillatelsen. Når retten gjennomgår opptaket, unngår den problemene knyttet til tilltrobevisning.

Både i Finland og Sverige kan retten fremme en del av en sak. ${ }^{37}$ I Sverige kan dette bare skje dersom delen som fremmes, er uavhengig av andre deler av anken. Retten kan for eksempel fremme spørsmålet om erstatningsbeløpet, men nekte spørsmålet om ansvarsgrunnlaget fremmet, men ikke motsatt. I Finland kan retten beslutte å fremme en del av anken og vente med å avgjøre spørsmålet om å fremme resten av anken inntil den første delen er avgjort.

Det andre trinnet av saksbehandlingen, omprøvingen, er oftest skriftlig. I Sverige ble $13,4 \%$ av alle ankesaker avgjort etter muntlig forhandling. ${ }^{38}$ Gjennomsnittlig tid i rettsmøte var 8 timer. I Finland er

\footnotetext{
${ }^{34}$ SvRB 50 kap. 4 § og fiRB 25 kap. 15 §.

${ }^{35}$ SvRB 49 kap. 14 § og fiRB 25a kap. 11 §.

${ }^{36}$ SvRB 50 kap. 23 § og fiRB 26 kap. 15 §. Nærmere om doktrinen om «tilltro», se Anna Nylund, Tillgången till den andra instansen i tvistemål, Suomalainen Lakimiesyhdistys 2006, s. 144 ff., og Lars Welamson og Johan Munck, Processen i hovrätten och Högsta Domstolen: Rättegång VI, 4. utgave, Norstedts Juridik 2011, s. 81 ff.

${ }^{37}$ SvRB 49 kap. 14a § og fiRB 25 a kap. 12 §.

${ }^{38}$ Domstolsstatistik 2018, s. 18-20.
} 
tilsvarende tall $22 \%$, altså vesentlig høyere, mens den gjennomsnittlige tiden brukt i rettsmøter er 6,5 timer. ${ }^{39}$

Dersom saksbehandlingen er skriftlig, kan retten be partene om å sende ett prosesskriv om ett eller flere spørsmål. Retten har ikke anledning til å innhente flere prosesskriv med mindre særlige grunner foreligger. ${ }^{40}$ Ved behov kan ankedomstolen bruke opptak fra underretten i tillegg til skriftlig materiale.

Ankeforhandling holdes som regel bare dersom anken gjelder bevisspørsmål og partene legger frem muntlige bevis. Ankeforhandlingen har begrenset omfang og konsentreres først og fremst om føring av muntlige bevis. I Sverige brukes som regel videoopptak fra underretten med eventuelle supplerende spørsmål. I Finland er prosessen basert på bevisumiddelbarhet slik at det foretas et nytt vitneavhør. Opptak brukes likevel der vitnet ikke kan møte på grunn av sykdom eller lignende, og der et vitne har endret forklaring i ankeinstansen. Opptak kan også brukes for å bidra til en helhetlig fremstilling av saken. ${ }^{41}$

\section{Tysk rett}

Den tyske prosessen er, i likhet med den norske, basert på muntlighet og umiddelbarhet.

Saksforberedelsen har en sentral rolle, med en aktiv saksforberedende dommer og med særlig vekt på retten til kontradiksjon og vern mot overraskende avgjørelser. Rettssystemet er mer domstolsentrert enn det vi er vant til i Norge: Bruken av alternative tvisteløsningsorganer er lav og antallet rettssaker tilsvarende høyt. Av ca. 1,2 millioner innkomne sivile saker ble ca. 95000 (ca. 7 \%) anket i $2017 .^{42}$ Retten til anke er ikke i seg selv vernet i den tyske grunnloven, men retten til en rettferdig rettergang (rechtliches Gehör) har grunnlovsvern, og som en følge av dette må partene ha rett til å anke dersom retten til en rettferdig rettergang er krenket. Det rår imidlertid uenighet om hvorvidt det er en grunnlovsvernet ankerett utover dette. ${ }^{43}$

Retten til anke er betinget av at ankegjenstandens verdi overstiger 600 euro, eller at underretten gir sitt samtykke. ${ }^{44}$ En avgjørelse som er anket, kan ikke tvangsfullbyrdes med mindre underretten eller ankedomstolen tillater det, eller et av flere unntak i loven kommer til anvendelse. ${ }^{45}$

Den gjennomgripende reformen av den tyske sivilprosessen i 2001 innebar en overgang fra en nesten ubegrenset rett til prøving til et system basert på overprøving. En av de viktigste delene av reformen var å innføre preklusjon mellom instansene, en adgang til å nekte anker fremmet og sterkere begrensninger

${ }^{39}$ Samme sted, s. 18-20 og Tuomioistuinten työtilastoja vuodelta 2018, s. 8.

${ }^{40}$ SvRB 50 kap. $10 \S$ og fiRB 26 kap. 8 §.

${ }^{41}$ Welamson og Munck 2011, s. 90-92 og Frände mfl. 2012, s. 1154-1163.

${ }^{42}$ Av 911644 avgjorte saker i Amtsgericht (lokal domstol) oversteg tvistesummen 10000 euro i bare 2,4 $\%$ av sakene (ca. 24000 saker), og i nesten halvparten av sakene var tvistesummen under 1000 euro. I Landgericht (tingrett) var verdien på tvistegjenstanden under 10000 euro i $36 \%$ av de 307 990 sakene som ble avgjort i 2017, jf. Statistisches Bundesamt, Rechtspflege Zivilgerichte 2017, Fachserie 10 Reihe 2.1, s. 26 og 56.

${ }^{43}$ Retten til en rettferdig rettergang tolkes vidt og omfatter blant annet en rett til materiell prosessledelse, se Leo Rosenberg, Karl Heinz Schwab og Peter Gottwald, Zivilprozessrecht, 18. utgave, C. H. Beck 2018, s. 462-468.

${ }^{44} \mathrm{ZPO} \S 513$.

${ }^{45}$ ZPO §§ 537 og 708 ff. 
i ankebehandlingen. For eksempel skal ankedomstolen legge underrettens bevisvurdering til grunn for sin avgjørelse med mindre den ankende part har fremsatt konkrete indikasjoner på feil som har betydning for avgjørelsens innhold. ${ }^{46}$ Feilene kan dreie seg om prosessuelle feil i forbindelse med bevisførselen, uklarheter knyttet til et bevis eller vurderingen av et bevis, eller at gjengivelsen av vitneforklaringen i rettsboken eller dommen ikke samsvarer med slutningene. Det foreligger en presumsjon for at underretten har avgjort bevisspørsmålene riktig, og at ankedomstolen dermed skal legge underrettens bevisvurdering til grunn, og ikke omprøve bevisspørsmålene. ${ }^{47}$

Partene kan ikke legge frem nye bevis eller påberope seg nye omstendigheter for ankedomstolen. «Nye» henviser til bevis og omstendigheter som var tilgjengelige og relevante på tidspunktet for hovedforhandlingen i underretten. ${ }^{48}$ Bevis og omstendigheter som har oppstått eller blitt relevante etter dette tidspunktet, omfattes ikke av begrensningen. Nye bevis og omstendigheter kan likevel påberopes dersom (1) de gjelder forhold eller synspunkter som underretten har oversett eller ansett for å være uten betydning, (2) en prosessuell feil har hindret parten fra å fremlegge beviset eller påberope seg omstendigheten, for eksempel at underretten feilaktig har avskjært bevisene, eller (3) grunnen til at parten ikke frembragte beviset, var annet enn slurv (Nachlässigkeit). Partenes adgang til å endre sine krav og påstander forutsetter at motparten samtykker, eller at retten anser det som hensiktsmessig, ${ }^{49}$ og i tillegg må endringen underbygges av omstendigheter og bevis som allerede var påberopt $\mathrm{i}$ underretten, eller som kan påberopes i tråd med ovennevnte unntak. Av hensyn til å få materielt riktige avgjørelser og prosess $\varnothing$ konomi håndheves ikke reglene særlig strengt. ${ }^{50}$

En ankedomstol kan nekte en sak fremmet dersom det er åpenbart at anken ikke vil føre frem og saken heller ikke reiser spørsmål av betydning for andre saker. ${ }^{51}$ Avgjørelsen må være enstemmig og skal begrunnes. Den saksforberedende dommeren har plikt til å varsle partene om en slik avgjørelse. Følgen er ikke sjelden at anken trekkes. Bestemmelsen har vært gjenstand for kritikk og debatt, ${ }^{52}$ ikke minst på grunn av merkbare forskjeller mellom domstolene. I snitt ble ca. $15 \%$ av ankene nektet fremmet. Omtrent dobbelt så mange anker ble trukket og like mange forlikt. Variasjonene mellom de enkelte ankedomstolene er likevel store (fra 1,6 \% til $32 \%$ ). ${ }^{53}$

Saksbehandlingen i ankedomstolen er muntlig i cirka halvparten av sakene, og alltid når partene presenterer muntlige bevis, uavhengig av om bevisene er nye eller har vært lagt frem i underretten.

\footnotetext{
${ }^{46} \mathrm{ZPO} \S 529$.

${ }^{47}$ Adolf Baumbach mfl., Zivilprozessordnung: Kommentar, 72. utgave, C. H. Beck 2014, s. 1798-1801.

${ }^{48} \mathrm{ZPO} \S 531$.

${ }^{49} \mathrm{ZPO} \S 533$.

${ }^{50}$ Baumbach mfl. 2014, s. 1803-1809.

${ }^{51} \mathrm{ZPO} \S 522$.

${ }^{52}$ Se f.eks. Erich Waclawik, «Aufruhr im Auenland: Was wird aus der Nichtzulassungsbeschwerde?», Neue Juristische Wochenschrift, 2016 s. 1639-1644, og Caroline Meller-Hannich, «Die Neufassung von § 522 ZPO: Unbestimmte Rechtsbegriffe, Ermessen und ein neuartiges Rechtsmittel», Neue Juristische Wochenschrift, 2011 s. 3393-3397. Ordningen har vært omtvistet og kritisert fra tiden før den ble vedtatt, se Nylund 2006, s. 259.

${ }^{53}$ Rechtspflege Zivilgerichte 2017, s. 68-75 og 94-101.
} 
Saksbehandlingen begrenses til de deler av saken som er anket, samt prosessuelle spørsmål som retten skal ta stilling til av eget tiltak. ${ }^{54}$

En kuriositet i tysk rett er at selv om ankedomstolen i utgangspunktet skal settes med tre fagdommere, kan en enkeltdommer avgjøre anker over dommer dersom saken ikke reiser særlig vanskelige eller prinsipielle spørsmål. ${ }^{55}$ Fordi en dommer alene avgjør de aller fleste sakene i underretten, har ankeinstansen et vidt skjønn i bruken av enedommere. Hensikten er å spare ankeinstansenes ressurser. ${ }^{56}$

\section{Spansk rett}

Den spanske sivilprosessen ble gjennomreformert da Ley de Enjuiciamiento Civil (LEC) ble vedtatt i år 2000 og satt i verk året etter. Da ble restene av den gamle legale bevisretten forlatt til fordel for et fritt bevissystem, noe som ble kombinert med de samme prinsippene om effektivitet og proporsjonalitet som ble så sentrale også i andre europeiske reformer fra samme tid. Ambisjonen med den nye reformen var å sette dommeren i best mulig posisjon til å avsi en god dom. Den gamle tradisjonen med skriftlig saksbehandling ble erstattet med en muntlig prosessform. I tillegg ble en streng forståelse av disposisjonsprinsippet og partsautonomien videreført. Det medfører at partene ikke bare har ansvaret for å påberope fakta, men også rettslige argumenter. ${ }^{57}$ Både faktiske og rettslige argumenter skal legges frem så tidlig som mulig, jf. LEC artikkel $400 \mathrm{nr} .1:^{58}$

«When what is requested in the claim may be based on several facts or on different legal grounds or entitlements, the claim must include all those which are known or may be invoked when the claim is lodged, and it is not admissible to reserve an allegation for subsequent proceedings.»

Begge partene må altså vise alle sine kort så tidlig som mulig, slik at begge parter helt i starten av førsteinstansprosessen skal kunne gjøre seg opp en velgrunnet mening om hvordan saken står. Fra dette utgangspunktet gjøres likevel visse snevre unntak som medfører at man etter omstendighetene kan påberope faktiske forhold eller bevis som har oppstått eller blitt oppdaget på et senere tidspunkt. ${ }^{59}$ Disse grunntrekkene gir føringer for reglene om anke til andreinstans. De primære avgjørelsene i saken skal tas av en førsteinstans som er best mulig informert om sakens faktiske og rettslige sider, og ankeinstansens funksjon er å avgjøre om førsteinstansdommen er riktig, basert på det prosessmaterialet som var tilgjengelig for den første instansen. Ankeinstansen skal derfor i utgangspunktet ikke ha tilgang til mer prosessmateriale enn førsteinstansen hadde.

${ }^{54}$ ZPO §§ 528 og 529.

${ }^{55} \mathrm{ZPO} \S 526$.

${ }^{56}$ Etter ZPO § 348 er det obligatorisk med tre dommere for visse sakstyper, blant annet handelsrettslige saker og saker om bestemte saksforhold, blant annet saker mot banker og andre finansinstitusjoner, se Rosenberg mfl. 2018, s. 114-115 og 870. Bruken av enedommer varierer avhengig av sakens verdi. For saker med tvistesum i underretten på maksimalt 5000 euro ble saken avgjort av én dommer i ankeinstansen i $16 \%$ av sakene, mens andelen er $2 \%$ i saker med høyere tvistesum, se Rechtspflege Zivilgerichte 2017, s. 80 og 108.

${ }^{57}$ LEC art. 216.

${ }^{58}$ Oversettelsen finnes her, men ikke med fri tilgang: https://www.mjusticia.gob.es/cs/Satellite/Portal/es/servicios-ciudadano/documentacionpublicaciones/publicaciones/traducciones-derecho-espanol.

${ }^{59}$ LEC art. 286. 
Den spanske konstitusjonen gir ingen beskyttelse av retten til å anke i sivile saker. Konstitusjonen har riktignok et krav om "effective remedy» à la EMK artikkel $13,{ }^{60}$ men det gjelder bare for overtredelser av menneskerettigheter, og rettsmidlet trenger ikke nødvendigvis å være en ankerett. Det følger likevel av LEC at alle dommer, unntatt dommer om formueskrav som har en verdi under 3000 euro, kan ankes. ${ }^{61}$

For ankeinstansen kan partene bare introdusere krav som var blitt gjort gjeldende for førsteinstansen. En detaljert ankeerklæring leveres til førsteinstansdomstolen, og det er den domstolen som forkynner anken for motparten, og som mottar anketilsvaret. Det er også førsteinstansdomstolen som tar stilling til om de formelle vilkårene for å anke er oppfylt, og som sender alle sakens dokumenter videre til ankeinstansen. Ankeprosessen er i hovedsak skriftlig, og en muntlig høring blir bare holdt i de ganske uvanlige tilfeller hvor det skal føres nye bevis for ankedomstolen, eller i de enda sjeldnere tilfeller hvor partene eller domstolen mener at en muntlig høring er $n \varnothing d v e n d i g .{ }^{62}$ Denne overgangen til skriftlig ankebehandling var kanskje den viktigste endringen av ankeprosessen ved reformen i år 2000, og det er en skarp kontrast mellom dagens skriftlige behandling og den muntlige ankebehandlingen som var vanlig før. Grunnen til at man gikk over til skriftlig ankebehandling, og i stedet innførte muntlig førsteinstansbehandling, var at de muntlige ankebehandlingene tok for lang tid og skapte store restanser. Med det nye skriftlige regimet har tidsbruken for ankeinstansene blitt redusert fra flere års behandlingstid til 5-7 måneder.

Ankedomstolens oppgave er som sagt å kontrollere om førsteinstansdommen er riktig, basert på det materialet som var tilgjengelig for førsteinstansdomstolen, ikke å foreta en helt ny prøving av saken. Partene kan derfor bare kreve dom for de kravene som var oppe i første instans, og de kan ikke påberope nye påstandsgrunnlag eller føre nye bevis utover de som var gjort tilgjengelige i første instans. ${ }^{63}$ Ankedomstolens kompetanse er dessuten begrenset av partenes disposisjoner; det er bare de delene av førsteinstansdommen som er uttrykkelig anket over, som kan behandles av ankedomstolen, alt annet blir endelig avgjort. ${ }^{64} \mathrm{Hvis}$ ankedomstolen finner at førsteinstansdomstolen hadde begått visse feil, er hovedregelen at den skal avsi den dommen som skulle ha vært avsagt i første instans dersom feilen ikke hadde vært begått. Dette er imidlertid annerledes dersom ankedomstolen kommer til at førsteinstansdomstolen hadde begått en prosessuell feil før dommen ble skrevet: Da vil det ofte bli en ny førsteinstansbehandling. ${ }^{65}$

Partene kan gjøre gjeldende alle mulige grunner de mener å ha for at førsteinstansdommen er feil, og LEC regner opp tre kategorier av ankegrunner: i) feil i bedømmelse av faktiske forhold, ii) feil i rettsanvendelsen, iii) saksbehandlingsfeil. ${ }^{66} \mathrm{Hvis}$ det er anket over sakens faktiske sider, vil ankedomstolen i første omgang vurdere om førsteinstansdomstolen gjorde en forsvarlig vurdering av bevisene den hadde tilgjengelig. Unntaksvis kan en part få ført nye bevis direkte for ankedomstolen, men bare dersom: 1) beviset først hadde oppstått etter tidspunktet da det skulle ha blitt introdusert for

\footnotetext{
${ }^{60}$ Den spanske grunnloven art. 24.

${ }^{61}$ LEC art. 455.

${ }^{62}$ LEC art. 464.

${ }^{63}$ LEC art. 456 nr. 1.

${ }^{64}$ LEC art. 458 nr. 2.

${ }^{65}$ LEC art. 465 nr. 4.

${ }^{66}$ LEC art. 459.
} 
førsteinstansdomstolen; 2 ) dersom den som vil føre det nye beviset, kan vise at han verken visste eller burde visst om det mens saken stod for førsteinstansen; 3) dersom beviset var umulig å få tilgang til tidligere og parten hadde nevnt beviset under førsteinstansbehandlingen; eller 4) dersom beviset feilaktig var blitt avskåret av førsteinstansdomstolen. Ankedomstolen er altså ikke helt uten mulighet for å tillate nye bevis, men det er viktig å understreke at dette er unntak som ikke uten videre kommer til anvendelse.

En dom har tvangskraft allerede fra den er avsagt, og en anke medfører ikke at tvangskraften suspenderes. Fullbyrdelsesdommer fra en førsteinstansdomstol kan altså tvangsgjennomføres selv om dommen har blitt anket. ${ }^{67}$ Også dette er et uttrykk for et system hvor førsteinstansdommen skal respekteres og regnes som gjeldende rett inntil det motsatte eventuelt viser seg å være tilfellet. Eneste unntaket her gjelder for dommer som tilkjenner erstatning på grunn av ærekrenkelser. ${ }^{68}$

For tiden er ingen reformer av ankeadgangen på trappene i Spania. De temmelig strenge reglene om anke og ankebehandling ser ut til å bli praktisert slik de er tiltenkt, og ankefrekvensen er ikke veldig høy. I tidsrommet fra 2008 til 2017 ble dommene fra de alminnelige førsteinstansdomstolene anket i noe under $15 \%$ av sakene, og omtrent det samme var tilfellet for førsteinstansdommer fra de kommersielle domstolene. Tallene fra 2017 viser også at $61,4 \%$ av dommene fra ordinær førsteinstans ble opprettholdt fullt ut av ankedomstolen, og at det samme gjaldt for 55,5\% av dommene fra de kommersielle domstolene. Bare $15,7 \%$ av sakene fra ordinær førsteinstans ble totalt omgjort av ankeinstansen, mens det samme gjaldt for $19,4 \%$ av sakene fra de kommersielle domstolene. Noe over $20 \%$ av dommene fra ordinær førsteinstans ble delvis omgjort, mot $16,8 \%$ av sakene fra de kommersielle domstolene.

\section{Fransk rett}

Reglene om anke i fransk rett bygger på et de novo-prinsipp, det vil si at ankebehandlingen skal være en full ny prøving av alle forhold ved saken. Partene kan riktignok ikke, med mindre bestemte unntak er oppfylt, trekke inn andre krav enn de som var påberopt for førsteinstans ${ }^{69}$ Men så lenge det er snakk om samme krav som ble behandlet i første instans, kan partene trekke inn alle relevante forhold. Dette kommer til uttrykk i Code de procédure civile (CCP) artikkel 563, som i engelsk oversettelse ser slik ut: ${ }^{70}$

«To support on appeal the claims submitted before a lower judge, parties may raise new grounds, produce new documents or offer new evidence.»

Det er altså ingen form for preklusjon mellom instansene i fransk rett: Dersom et bevis, et påstandsgrunnlag eller et rettslig argument ikke var fremme under førsteinstansbehandlingen, kan det likevel trekkes inn under ankebehandlingen så lenge det er relevant for et krav i saken.

Denne meget sjenerøse ankeregelen henger sammen med saksbehandlingsmåten i fransk rett. I Frankrike er saksbehandlingen i all hovedsak skriftlig både i første instans og i andre instans. Dessuten

${ }^{67}$ LEC art. 526.

${ }^{68}$ LEC art. 525 nr. 3.

${ }^{69}$ CCP art. 564 til 567.

${ }^{70}$ Oversettelsen finnes her: https://www.legifrance.gouv.fr/Traductions/en-English/Legifrancetranslations. 
har fransk rett vidtgående sanksjoner, både erstatningsrettslige og andre, mot personer som misbruker ankeretten. ${ }^{71}$ For anker som gjelder formueskrav, kreves anketillatelse dersom ankesummen er under 5 000 euro. $^{72}$

I løpet av de siste 20 årene har det vært flere fors $\varnothing k$ på å reformere de franske ankereglene. Det skyldes blant annet at antallet anker er temmelig høyt: over 250000 per år. Det ankes i cirka $20 \%$ av sakene generelt, og i hele $67 \%$ av alle arbeidsrettslige saker. ${ }^{73}$ Ankedomstolene har lange restanser, og flere av dem bruker i gjennomsnitt nesten to år fra anken kommer inn til dom blir avsagt. ${ }^{74}$ Reformene har i første rekke medført kortere frister for å utføre ulike former for prosesshandlinger, og dessuten er det innført en form for digital kommunikasjon mellom retten og partene. Man har ikke i særlig grad innskrenket de novo-prinsippet, og de fleste franske forfattere ser ut til å forsvare prinsippet. Likevel virker det som noen innskrenkninger av ankedomstolens kompetanse er aktuelt, og en overgang til overprøving i stedet for ny behandling blir nevnt som en mulig fremtidig reform. ${ }^{75}$

\section{Norsk rett - hva må gjøres?}

Et komparativt blikk på ankereglene i de landene vi har gjennomgått, viser at det er temmelig store variasjoner mellom landene, men samtidig visse tendenser som er felles for de fleste av dem. Etter vår oppfatning kan flere av de typiske utviklingstrekkene for de fleste av landene ha interesse også for en reform av de norske ankereglene. Selv om en rett til å anke er forutsatt i Grunnloven § 88 første ledd og dessuten ser ut til å kunne tolkes inn i § 95 første ledd andre setning, ${ }^{76}$ vil det neppe sette videre praktiske begrensninger for hvordan reglene om ankebehandlingen utformes.

Hva gjelder innholdet i ankebehandlingen, er det spesielt fransk rett som skiller seg ut. Det er interessant å merke seg at fransk rett, som ett av meget få rettssystemer i Europa, fortsatt bygger på et de novo-prinsipp, og at prinsippet ser ut til å fungere noenlunde bra. Men de som eventuelt vil ta fransk rett som utgangspunkt eller inspirasjon for en reform av ankereglene i Norge, bør merke seg at fransk rett på visse fundamentale punkter avviker sterkt fra norsk rett: Som sagt er saksbehandlingsmåten i fransk rett, både i første og andre instans, i all hovedsak skriftlig. Dette er en så markant og gjennomgående forskjell fra det sterke muntlighetsprinsippet i norsk rett at det sterkt svekker den rettspolitiske overføringsverdien av franske løsninger. For ankereglene er det grunn til å understreke dette fordi et skriftlig system medfører at kostnadene ved å gjennomføre prosesshandlinger på nytt for ankeinstansen blir mindre enn i et muntlig system. Å sende skriftlige vitneutsagn også til ankeinstansen

${ }^{71}$ Samme sted, s. 84.

${ }^{72}$ Frem til 1.1.2020 er ankesummen 4000 euro, Code de l'organisation judiciaire art. R221-4 og R22137.

${ }^{73}$ Emmanuel Jeuland, Introduction to French Business Litigation, Joly 2016, s. 181-182.

${ }^{74}$ Samme sted, s. 182.

${ }^{75}$ Samme sted, s. 182.

${ }^{76}$ Utover en del utsagn om retten til å anke i straffesaker er retten til å anke kort nevnt som eksempel på hva som kan være omfattet av det generelle kravet om «rettferdig rettergang», se Dokument 16 (2011-2012) Rapport til Stortingets presidentskap fra Menneskerettighetsutvalget om menneskerettigheter i Grunnloven, s. 118. Se også Rt. 2015 s. 334 og mindretallets votum i Rt. 2015 s. 506. Se også Jørgen Aall, Rettsstat og menneskerettigheter, 5. utgave, Fagbokforlaget 2018, s. 524-525. 
innebærer vesentlig mindre merarbeid enn et nytt vitneavhør for andre instans eller å bruke opptak av vitneavhøret som fant sted i første instans. Kostnadene ved å gå til domstolene er også atskillig lavere i Frankrike enn i Norge, slik at en vid ankebehandling ikke på samme vis vil heve terskelen for å gå til domstolene med sin sak.

De fire andre landene - Tyskland, Spania, Sverige og Finland - følger imidlertid et muntlighetsprinsipp i første instans. ${ }^{77}$ Sett fra et norsk perspektiv er det da interessant å merke seg at alle disse fire landene i løpet av de siste 20 årene har gjennomført dyptgående reformer av reglene om anke til andre instans, og at utviklingen i alle landene har gått i retning av å innskrenke det som skal være tema for en ankebehandling. Det virker som disse landene har klart å gjennomføre en overgang fra full omprøving til begrenset overprøving, slik at det kan hevdes at de har satt ut i livet det ankebehandlingssystemet som den norske lovgiver hevdet at tvisteloven skulle innebære. Sammenlignet med de norske reglene er det flere trekk som avviker. Disse trekkene er langt på vei essensen i overprøvingssystemet.

For det første har alle disse fire landene temmelig strenge regler om preklusjon mellom instansene. Dette medfører at anken ikke kan angå andre krav enn det som var tema i første instans, partene kan ikke utvide sin påstand sammenlignet med påstanden som ble nedlagt i første instans, partene kan ikke påberope andre faktiske forhold enn det som var påberopt i førsteinstansen, og de kan heller ikke fremlegge andre bevis enn de som var fremlagt i første instans. Alle de fire landene har enkelte modifikasjoner av dette, men modifikasjonene kommer bare til anvendelse dersom visse helt bestemte vilkår er oppfylt. Også norsk rett har regler som medfører at partene som hovedregel ikke kan gjøre gjeldende andre krav i ankeinstansen enn det som var gjort gjeldende i førsteinstansen, og heller ikke kan utvide påstanden sammenlignet med det som var gjort gjeldende i førsteinstansen, jf. tvisteloven $\S$ 29-4 (2) og (3). Men for de vel så praktisk viktige spørsmålene om påberopelse av nye påstandsgrunnlag og føring av nye bevis for lagmannsretten, er det bare hovedbestemmelsene om preklusjon i tvisteloven $\S 9-16$, jf. § 29-18 og § 16-6 (3), som kommer til anvendelse. De bestemmelsene innebærer bare at en prosesshandling kan prekluderes dersom den er meldt for sent innenfor en instans, den innebærer ikke preklusjon mellom instansene. Lagmannsretten kan dermed prekludere dersom en prosesshandling ble meddelt for sent for lagmannsretten, men lagmannsretten kan ikke prekludere med den begrunnelse at prosesshandlingen ikke var foretatt for tingretten. ${ }^{78}$ Denne rettstilstanden er det grunn til å endre. For effekten av den kan fort bli at lagmannsrettsbehandlingen blir mer omfattende enn tingrettsbehandlingen, den kan medføre at grove forsømmelser gjort av en part i tingretten, ikke får noen effekt, og den kan gi den parten som har fått en prosesshandling prekludert i tingretten, et utilsiktet insentiv til å anke. Dagens rettstilstand legger til og med til rette for at enkelte parter spekulerer i å ikke fremlegge bevis eller påstandsgrunnlag for tingretten, slik at det hele skal komme mer overraskende under lagmannsrettsbehandlingen. Preklusjon mellom instansene vil også kunne hindre at saksbehandlingen i tingretten blir en «prøverunde», men det vil antakelig forutsette at saksforberedelsen i tingretten styrkes.

For det andre er det i alle disse fire landene slik at partene først må overbevise ankeinstansen om at underrettens avgjørelse eller saksbehandling er eller kan være beheftet med feil, eventuelt at saken

\footnotetext{
${ }^{77}$ Se Anna Nylund, «The structure of civil proceedings - convergence through the main hearing model?», Civil Procedure Review, No 2 2018, s. 13-39.

${ }^{78}$ Jf. Rt. 2010 s. 1143, Rt. 2012 s. 1483 og HR-2019-223-U (avsnitt 16).
} 
reiser spørsmål av betydning for andre saker. I norsk rett er det langt på vei tilstrekkelig at en part på en konkret nok måte pretenderer at den ankede dommen lider av en feil, og saken skal da fremmes til ankebehandling med mindre det er «klart at anken ikke vil føre frem», jf. tvl. § 29-13 (2). Det virker som det skal ganske mye til før lagmannsretten anvender denne anledningen til å nekte en anke fremmet, og når anken først blir fremmet, så kan ankebehandlingen dreie seg også om helt andre ankegrunner enn de anken opprinnelig var bygget på. I andre land er den etterfølgende prøvingen begrenset til de deler som kan være beheftet med feil. Også i norsk rett er det god grunn til å gjennomføre et slikt hardere konsentrasjonsprinsipp. ${ }^{79}$ Tvisteloven bygger allerede på et slikt prinsipp, jf. § 1-1 (2) og § 29-18 (1), og også for ankebehandlingen var det som sagt et mål at den i større grad skulle konsentreres om det som hevdes å være feil i førsteinstansdommen. Når dette målet bare i liten grad har blitt oppnådd, kan det henge sammen med at de norske ankereglene i for stor grad overlater ankebehandlingens innhold til partene.$^{80}$ Selv om det er vel og bra at partene må konkretisere sine ankegrunner, vil partene ved å kumulere ankegrunner og gi et bredt prosessopplegg for ankeinstansen i praksis kunne oppnå at det blir full omkamp. I mange store saker er det også fullt forståelig at begge parter ønsker å spille ut alle sine kort med mindre det finnes lovbestemmelser som hindrer det.

For det tredje er skriftlig saksbehandling etter hvert blitt mer utbredt for ankebehandlingen. Tvisteloven åpner til en viss grad for skriftlig saksbehandling, jf. § 9-9 (2) til (4) og § 29-16 (4) og (5). Loven domineres likevel av en sterk hovedregel om at det som er tvistegjenstand i saken, skal avgjøres etter muntlig saksbehandling i form av full hovedforhandling, jf. § 9-9 (1), § 9-14 (1) og § 29-16 (1). Tvisteloven § 29-16 (5) gir lagmannsretten noe videre muligheter for å bestemme skriftlig saksbehandling enn det som gjelder for tingretten, men bare dersom anken utelukkende dreier seg om saksbehandlingen og rettsanvendelsen, eller dersom anken «bare i liten grad angår faktiske spørsmål hvor umiddelbar bevisføring vil være av vesentlig betydning». I resten av Europa er bildet noe annerledes. Med unntak for Tyskland er skriftlighet hovedregelen for ankeprosessen, og Spania innførte som sagt et nytt system der ankebehandlingen nå er strengt skriftlig. I Sverige og Spania brukes også opptak fra underretten i stor grad, mens Finland og Tyskland praktiserer direkte bevisførsel. I Norge er en utvikling i retning av å bruke mer teknologi på vei, men etter vårt syn kan det være god grunn til å vurdere om ikke også større deler av selve ankebehandlingen skal foregå skriftlig. ${ }^{81}$ Et alternativ kan være å ha en hovedregel om skriftlig saksbehandling som anvendes med mindre helt eller delvis muntlig saksbehandling er nødvendig på grunn av behov for ytterligere vitneførsel, eller dersom det av andre grunner skulle være nødvendig for å få en forsvarlig saksbehandling.

For det fjerde er det som sagt i enkelte andre land slik at ankeinstansen i temmelig stor grad bare skal legge til grunn det faktumet som førsteinstansdomstolen hadde lagt til grunn for sin avgjørelse. I tysk rett er det som sagt en sterk presumsjon for at førsteinstansdomstolen har avgjort bevisspørsmålet riktig, og det er i utgangspunktet ikke slik at andreinstansen skal gjøre en ny bevisvurdering i saken. For

${ }^{79}$ Antakelig må behandlingen i tingretten konsentreres, i tillegg til grepene som bør gjøres i lagmannsretten. For en komparativ analyse om hvordan saksbehandlingen kan konsentreres, se Anna Nylund, «Saksforberedelsen i tvistemål i et komparativt perspektiv», i Magnus Matningsdal og Asbjørn Strandbakken (red.), Integritet og cre: Festskrift til John Henry Mceland, Universitetsforlaget 2019, s. 414-429.

${ }^{80}$ Se også Øyen 2018, s. 389-390.

${ }^{81}$ NOU 2019: 17 Domstolstruktur, punkt 10.2. 
norsk retts vedkommende reiser dette et interessant og ganske radikalt spørsmål: $B \varnothing r$ bevisbedømmelser være en av lagmannsrettens hovedoppgaver? Det er strengt tatt ingen grunn til å tro at lagmannsretten er bedre enn tingretten til å bed $\varnothing$ mme bevis, mange av bevisene - særlig vitnebevisene - har neppe blitt noe bedre av den tiden som har gått siden tingrettsbehandlingen, og det er heller ikke åpenbart at bevissituasjonen blir noe bedre av at partene har fått testet sine opplegg en gang i tingretten. I formuleringen av ankereglene bør man spørre seg om det er riktig å beholde «feil $\mathrm{i}$ bedømmelsen av de faktiske forhold» i tvisteloven § 29-3 (1) som en egen ankegrunn når den samme bestemmelsen også regner feil i saksbehandlingen eller rettsanvendelsen som egne ankegrunner.

En annen interessant observasjon er at verken Sverige eller Finland har et krav om ankesum, og at kravet i Tyskland er meget lavt - sumgrensen er bare 600 euro (gjeldende ankesum i Norge er 20 ganger høyere). ${ }^{82}$ Fordi for eksempel forbrukertvistel sning i høy grad skjer i domstolene i tysk rett, ikke i nemnder, rammer bestemmelsen i all hovedsak krav som ikke blir fremmet i norske og nordiske domstoler. Ankesummen i Spania er satt til 3000 euro, noe som tilsvarer litt mer enn en spansk gjennomsnittlig månedslønn, mens den norske grensen tilsvarer det tredobbelte av en gjennomsnittlig norsk månedsıøn. Alt dette viser at det er fullt mulig å bygge opp velfungerende ankesystemer uten at selve ankesummen trenger å være det sentrale.

Etter vår mening er problemene med de norske ankereglene stort sett de samme i dag som de var før tvisteloven ble vedtatt, nemlig at ankebehandlingen bærer preg av å være en full behandling, den er for dyr, og den tar for lang tid. De samlede kostnadene blir så høye at det kan gjøre terskelen for å gå til søksmål for høy, slik at mange saker ikke kommer inn for domstolene i det hele tatt. Og for de sakene som ender i domstolen, kan tingrettsbehandlingen lett bli oppfattet som en ren «test» fordi begge parter på forhånd vet at det uansett blir en full ny runde i lagmannsretten.

82 Jf. tvl. § 29-13 (1). 